\title{
Discursive Manipulations of Names and Naming in Kate Grenville's The Secret River
}

\section{Sheila Collingwood-Whittick}

\section{(2) OpenEdition \\ 1 Journals}

Electronic version

URL: https://journals.openedition.org/ces/5263

DOI: $10.4000 /$ ces.5263

ISSN: 2534-6695

Publisher

SEPC (Société d'études des pays du Commonwealth)

\section{Printed version}

Date of publication: 1 September 2013

Number of pages: 9-20

ISSN: 2270-0633

\section{Electronic reference}

Sheila Collingwood-Whittick, "Discursive Manipulations of Names and Naming in Kate Grenville's The Secret River", Commonwealth Essays and Studies [Online], 36.1 | 2013, Online since 16 April 2021, connection on 22 July 2021. URL: http://journals.openedition.org/ces/5263 ; DOI: https://doi.org/ $10.4000 /$ ces.5263

\section{(c) $(1)$}

Commonwealth Essays and Studies is licensed under a Licence Creative Commons Attribution - Pas d'Utilisation Commerciale - Pas de Modification 4.0 International. 


\section{Discursive Manipulations of Names and Naming in Kate Grenville's The Secret River ${ }^{1}$}

Although Kate Grenville's Colonial Trilogy frequently signals the author's awareness both of recent Australian historiography and of postcolonial theorising on colonial thetoric and colonising practices, the author seems oblivious of certain reflexes (both psychological and ideological) that infiltrate her writing, subverting her declared intention of telling the truth about Australia's frontier history. By analysing the function of names and naming in The Secret River, I show how Grenville's narrative works both to disguise the fiercely predatory logic that drives colonisation and to normalise the process of Aboriginal dispossession.

This article stems from two observations arising from my reading of Kate Grenville's three-part exploration of Anglo-Australia's frontier history. ${ }^{2}$ The first is that, contrary to Grenville's averred commitment to telling the unvarnished truth about the modern nation's shameful origins, her recent historical fiction betrays a refractory tendency to portray Australia's past in a sentimental light. The second is that names and the act of naming constitute a dominant strand in the narrative weave of each of the novels. In the discussion that follows I seek to demonstrate the existence of a causal link between these two apparently unrelated observations by showing that a recurrent narratorial emphasis on the affective importance that names of places, people and things assume in the life of the colonial subject constitutes a vital element in the "empathetic history" (Gall 95) of Australia's frontier era that Grenville is intent on creating. Although this analysis can be applied to all three of Grenville's colonial novels, ${ }^{3}$ the present article will focus solely on the trilogy's opening volume, The Secret River - the work in which the author's discursive manipulation of names is most transparent and the ideological direction the rest of her frontier saga will follow is clearly signposted.

Drawing on Camilla Nelson's idea of "the hermeneutic power of the fictional work, the way in which stories explain events in the world by endowing them with a special

1. Based on the life of Grenville's ancestor, Solomon Wiseman, The Secret River (2005) tells the story of William Thornhill, transported to New South Wales in 1806, after being convicted of stealing timber. Having acquired land on the Hawkesbury River, Thornhill hopes to become a successful settler until several destabilising encounters with local Aborigines make his growing family feel threatened. When the Thornhills' neighbours decide to exterminate the troublesome "savages," Will, in desperation, goes along with them.

2. The other two novels in the trilogy are The Lieutenant (2008) and Sarab Thornbill (2011). The former traces the trajectory of Daniel Rooke, a gifted child of modest origins who becomes an officer of the First Fleet. During the establishment of the penal colony in Sydney Cove, Rooke (based on the historical personage, William Dawes) forms a friendship with a young Aboriginal girl, Tagaran, (real name Patyegarang), from whom he learns elements of the local Indigenous language. When Rooke disobeys the Governor's orders to bring back the severed heads of six natives, he is expelled from the colony. The latter is a sequel to The Secret River and portrays the continuing repercussions of the massacre of Aborigines for Thornhill, his son Dick, and, above all, his daughter, the eponymous heroine. It is a novel about historical guilt and settler-descendant desire to atone for acts of inhumanity perpetrated against Indigenous peoples.

3. Just two examples: in The Lieutenant, Rooke's questioning of Tagaran in order to ascertain the Aboriginal names of things results in "two people [finding] common ground" (186). It is a romantic what-might-have-been version of Australian history that relies on the perception of Rooke/Dawes as an Enlightenment hero - an image which, historian Cassandra Pybus argues, is quite at odds with the historical reality. In Sarab Thornhill, the heroine considers that the re-naming of William Thornhill's adopted "half-caste" grand-daughter with an English Christian name constitutes "a kind of death" (150) for the child and, when the latter actually dies, embarks on a quest for atonement. Needless to say, Sarah's is a modern sensibility that in no way reflects mainstream settler attitudes in the nineteenth century to the forcible removal of Aboriginal children from their families. 
kind of coherence," (n.p.) I contend that The Secret River "explains" the horrifying violence of Australia's colonisation as a consequence of the psychic damage from which, as transportees and involuntary immigrants, the early settlers suffered. I further contend that it is by means of her frequent recourse to episodes exposing the powerful impact of names and acts of naming on her protagonists' emotional lives that Grenville seeks to establish the essential pathos of the settler condition. Indeed, I argue, it is through such episodes depicting the settler as victim that, Grenville's acknowledgement of settler violence notwithstanding, her novel constructs a fundamentally exculpatory explanation of frontier atrocities. Before pursuing this idea further, however, I will briefly outline the socio-political context in which The Secret River was written and published.

Significantly, much of the overwhelmingly favourable critical commentary ${ }^{4}$ that Grenville's Colonial Trilogy has received stems from what commentators perceive to be the unflinching truthfulness of the account these novels offer of Australia's colonisation. To appreciate fully the significance of that accolade (the not just literary but moral value it recognises in Grenville's work) requires, I think, some knowledge of settler Australia's relationship with its history - a relationship that is central to the argument I develop.

Once it had been identified by anthropologist W. E. H. Stanner in 1968, the necessity of disinterring the long-buried, guilty secret ${ }^{5}$ of the lawless and brutal practices employed to dispossess Australia's Indigenous peoples of their land became the sine qua non for much of the research undertaken by a new generation of Australian historians. ${ }^{6}$ Outraged by what they perceived to be a disavowal of the traditionally celebratory narrative of the nation's origins, Australian nationalists launched a vigorous counter-attack on what they contemptuously described as "black armband history." Keith Windschuttle, the leading crusader in the so-called "History Wars," denounced the new historiography as the invention of "people who hate their own country." However, what began as a series of skirmishes among historians subsequently went on to provoke a great number of casualties in non-academic Anglo-Australian circles, ${ }^{10}$ Kate Grenville being one such casualty.

4. Many of the "formidable array of plaudits" (Carr 201) Grenville received, both from the Australian and international press, are reproduced on the author's own official website under "Reviews."

5. Historian Mitchell Rolls refutes the idea that frontier atrocities were a secret in Australia. For him, " $[\mathrm{t}]$ he issue is not the lack of telling, it is the mechanisms that rendered functional a turning away from the evidence, the will to ignorance" (26, my italics).

6. The fact that this new historiography coincided in the late $1980 \mathrm{~s}$ and $1990 \mathrm{~s}$ with public enquiries into Aboriginal deaths in custody, and the forcible removal of Aboriginal children from their biological families, degraded even further the negative image of Australia's past that was emerging.

7. A phrase first used by historian Geoffrey Blainey in 1993.

8. As Pulford reminds us, the term is borrowed from the title of a book about a controversial exhibition organised by the Smithsonian Museum in 1994 (150). "There is, of course, a delicious irony in calling certain analytical differences "wars," while simultaneously denying that repetitive physical conflicts embedded in our history, in which many thousands of people died, can ever be typified by such an excessive term" (Evans 10).

9. Words used by Keith Windschuttle in a vituperative outburst aimed at historian Henry Reynolds during a public debate in Hobart. See Mark McKenna (2009).

10. By "casualties" I mean those "guilt-afflicted settler-Australians" whom Haydie Gooder and Jane Jacobs also dub "sorry people." Since becoming aware of "the injuries experienced by indigenous Australians," these "mainly white (and mostly from an Anglo-Celtic background), and largely middleclass" subjects have, claim Gooder and Jacobs, experienced "not only feelings of guilt but also the mantle of responsibility for assuaging such feelings." Sensing "the legitimacy of their national subjectivity to be compromised [...], ["sorry people"] begin to experience a form of settler melancholia" (232). 
Thanks to the enormous media attention the warring historians attracted, settler descendants suddenly found themselves confronted with a shatteringly different view of frontier history from the mythologised version disseminated via the ambient culture of White Australia. Throughout the previous century Australian schoolchildren had, Raymond Evans observes, been educated to believe in the essential peacefulness of their country's "settlement"11:

School Readers inculcated collective amnesia by presenting a land "entirely empty of inhabitants" before the British arrival. Federation poetry, celebrating the ethical bona fides of the new nation, trumpeted a theme of constant peace:

"We have no records of a bygone shame. / No red-writ histories of woe to weep"

claimed poet John Farrell; while Banjo Paterson in "How the Land Was Won" reiterated:

"we have no songs of strife, / Of bloodshed reddening the land." $(25)^{12}$

As far as Anglo-Australians were concerned, it was not just, however, a question of believing "their" country had been settled without bloodshed. According to Veronica Strang, "For most white Australians the early settlers are heroes, their lives celebrated in literature and art. They are a touchstone of identity deeply embedded in the national psyche" (48). Little wonder then that, for a population reared on stories of "settler heroics," the belated confrontation with the "brutalities and injustice" of colonisation that took place at the end of the twentieth century has resulted, to quote Haydie Gooder and Jane Jacobs, in "a seemingly irreparable rupture in [their] sense of a place in the nation" (235). ${ }^{13}$ The feeling of loss that Gooder and Jacobs identify - the sense among sympathetic settlers "that they have lost a properly constituted national selfhood" (Gooder and Jacobs 235) - can, I think, be assimilated to what Ron Eyerman has, in a different context, referred to as a "cultural trauma," that is to say "a dramatic loss of identity and meaning, a tear in the social fabric" (2).

Significantly, when Kate Grenville describes her own reaction on coming face to face with what she admits was her repressed knowledge about Australia's frontier past, it is precisely in the language of the cultural trauma victim that she speaks. Addressing a meeting of the Australian Psychoanalytic Society in 2006, she confessed that:

A great and complicated grief happened in that moment. Part of it was the grief of losing my unquestioned sense of belonging here. I had to allow in the idea that others had been here first. [...] It was a powerful sense of loss - an idea of myself as "native" had to be replaced by an idea of myself as "foreign." An idea of myself as "at one with the place" had to be replaced by the reality that I was descended from those who had tried to destroy the people who really had been "atone with the place." ("Unsettling the Settler")

11. My use of scare quotes for terms such as "settlement," "exploration," “open up" etc. in this article, is intended to reflect the highly sensitive character such terms assume when applied to the ideological minefield that Australia's post-1788 history has become over the last few decades. Since the 1990s, the utilisation of these and similar terms has, as historian Anna Clark reminds us, provoked a great deal of controversy within the context of history-teaching in Australian schools (4-6). The continuing attachment of Anglo-Australians to the notion of what happened after 1788 as "settlement" (as opposed to "invasion" - a term that might more accurately represent the historical truth from an Indigenous Australian point of view) can be observed in the prominence given by the national broadsheet, The Australian, to the preference voiced by Julia Gillard (then Education Minister) in 2007 for “the traditional interpretation of the nation's history, saying she believed Australia was 'settled,' rather than 'invaded”' (Ferrari and Wilson, my italics).

12. By thus concealing historical reality, claims Evans, "a major psychological problem with national accountability was generated. Its effects were wide-ranging and, for most white Australians, inclusive and enduring” (28).

13. Cf. Gooder and Jacobs' analysis with historian John Gillis's observation that it is the "sense of sameness over time and space" that constitutes "the core meaning of any individual or group identity" (3). 
Implicit in the author's statement are both an expression of guilt and an awareness that, as the Council for Aboriginal Reconciliation has long insisted, if the sense of culpability that currently taints the thinking settler's perception of the nation's origins is ever to be exorcised, this can only be achieved by recognising "the grim truth about the colonisation of Australia" (Attwood, "Unsettling Pasts" 247). ${ }^{14}$

Yet, I argue, the truth Grenville's fiction claims to portray, like the critical consensus which salutes that truth, is more a reflection of white-settler reluctance (or perhaps inability) to accept fully what Richard Mulgan has called "[the] moral horror of the colonial past" (Mulgan in Probyn-Rapsey 67). By analysing the work performed by names and the act of naming in The Secret River, I seek to show that, contrary to Grenville's declared objective, the novel betrays a seemingly irremediable authorial impulse to veer towards a more palatable explanation of Australia's colonial origins than that proposed by recent historical accounts.

\section{Placenames}

Let us take the role played by placenames in the life of Sal Thornhill, the novel's main female protagonist. For this homesick convict's wife the toponyms of London's East End are mnemonic talismans by means of which she conjures up and keeps alive the thick experiential reality, the affective texture, of the "Home" (always capitalised whenever she is the narrative's focaliser) from which transportation to Australia has uprooted her. The emotional resonance these names have for Sal is alluded to in numerous narratorial observations. The name of the grog-shop that the Thornhills open in Sydney Cove is depicted as an elegiac reminder of the last day of her life in London when she picked up "a broken piece of clay rooftile [...] in the sand by Pickle Herring Stairs" (89). Connecting her to a more familiar world than that in which she is now exiled, the very sound of the name is a source of secret gratification: "To everyone else, the grogshop was nothing more than Thornhill's, but she gave it a name: the Sign of the Pickle Herring, just for the pleasure of hearing the words in her mouth" (89). Emblematic of Sal's pre-colonial existence, names from the East London landscape - like the shard of worn clay which she interprets as "a promise that London was still there, on the other side of the world, and she would be there too one day" (89) - provide comfort and reassurance.

Thus it is the evocation of familiar toponyms, for instance, that gives Sal the psychic energy to rally when, after the birth of her first daughter, she appears to be dying of milk fever. Hearing a visiting neighbour pronounce the names "Eastcheap," "Grantley Street" and "All Hallowes," "[she] smiled and found the strength to nod. I know, she whispered, Stickley's draper round the corner. She sat up at last, propped weakly on the pillows, and ate a few good mouthfuls" (184-5).

14. A truth which, apart from the acts of genocide committed by early settlers, includes much more recent acts of "land injustice and flagrant human rights abuses," "the forced removal and attempted break-up of Indigenous families" and "racist government policies aimed at subjugating and controlling Indigenous people" (Ritter 118). Kate Grenville also clearly identifies The Secret River as constituting, in part at least, her effort to meet the challenge set by the CAR. She does this by locating her epiphany in the fleeting glance she shares with an Aboriginal woman at the end of a Reconciliation march and by referring to her subsequent investigations into the frontier life of her convict ancestor as "[taking] the plunge" and going "the hard way, through the deep water of [Australian] history" (Searching 13). As historian Mark McKenna notes, "the story of the frontier has become something of a right of passage for Australian writers, the key to explaining our very right to belong here" ("Writing the Past" 7). 
Yet, if Sal finds solace in keeping alive and in everyday circulation verbal markers of the "Home" she longs for, her ceaseless evocation of London toponyms creates a certain emotional dissonance between her and the rest of her family. Her singing of name-filled songs, her insistence on regularly "walking" (220) her offspring through Bermondsey, naming each street they pass en route, dismays her husband (220) and disconcerts the couple's Australian-born children for whom such names have no meaningful connotations. As the narrator observes, "[i]n their mouths, the very names of that other place had a peculiar sound" (217). "That other place," which Sal calls "Home" is "nothing more than a word" (219) to the next generation.

The narrative's foregrounding of Sal's emotional dependence on placenames whose referents are destined to remain forever inaccessible to her, and the problems this dependence creates in her relationships with those she loves, make of this involuntary immigrant a poignant figure. By thus encouraging the reader to view the settler condition in terms of the pathos of exile, this representational manoeuvre works to divert attention from "the grim truth about the colonisation of Australia" (Attwood, "Unsettling Pasts" 247) - namely the multiple and ongoing traumas the settler presence provoked among Australia's Indigenous peoples.

It is, I think, worth opening a brief parenthesis here to note that Grenville's insights into the power place names possess are restricted to settler society alone. On the profound cultural and spiritual importance that place names are accorded in Australian Indigenous societies, her narrative maintains an unbroken silence. Given the emphasis placed in recent decades by cultural geographers, sociolinguists and postcolonial theorists on how European place-naming practices contributed to what Patrick Wolfe calls the "eliminatory strategies" (103) of white-settler colonialism, this seems a curious omission in a novel purporting to reveal the truth about Australia's colonial past. Especially since, in the specific case of Australia, Paul Carter and Simon Ryan's reflections on the "exploration" of the continent have offered important new understandings of the act of place-naming as an assertion of hegemonic colonial power over its Aboriginal inhabitants. During the same period, anthropologists have also been assessing the profoundly damaging consequences that the erasure of Indigenous place names had for cultures that revolved around the community's relationship with land it had cared for since time immemorial. ${ }^{15}$ The fact is, however, that Grenville's incongruous choice of third person subjective narration with white protagonists as sole focalisers ${ }^{16}$ effectively prohibits her from providing any Aboriginal perspective on the destructive impact that acts of naming (a practice commonly employed by settlers to secure any claim to Indigenous peoples' land ${ }^{17}$ ) had on their lives.

One final point on the question of place names: as is the case for Sal, place names are used to reveal the emotional injuries from which Will Thornhill suffers. Unlike for Sal, however, the names of Will's old haunts in London's East End have predominantly negative associations. Permeated with bitter memories of the poverty and social

15. See the bibliography at the end of this essay for two collections of essays which provide considerable information on the subject: Hercus et al; Koch et al.

16. As I have pointed out in an earlier essay ("The Haunting" 135), the reasons Grenville has given for electing not to appropriate an Indigenous perspective are perfectly legitimate. However, other options - notably that of an omniscient third person narrator - could have been used to present a less inevitably biased point of view.

17. As Blackwood informs Thornhill: "All a person need do was find a place no one had already taken. Plant a crop, build a hut, call the place Smith's or Flanagan's and out-stare anyone who said otherwise” (121). 
oppression he experienced as a lighterman on the Thames, they signal his role in the narrative as a man whom life has treated unfairly (a man with whom, despite his eventual participation in the massacre of Aborigines, we are invited to empathise).

\section{Surnames and Nicknames}

I turn now to the names of Grenville's characters. In Searching for The Secret River (Grenville's memoir on the genesis and writing of The Secret River), the author explains that the "authentic late eighteenth century names" she uses in her novel are taken from the convict registers (187). ${ }^{18}$ That said, her choice of names nonetheless reflects an authorial tendency to schematise Australia's colonisation in terms of a somewhat simplistic opposition between good and bad colonisers. ${ }^{19}$ For instance, the names "Tom Blackwood" and "William Thornhill" are reminiscent of English toponyms - ordinary, mainstream, yeoman-like names that, by association, suggest the ordinary, mainstream decency of the settlers who bear them. ${ }^{20}$ By contrast, those who commit atrocities such as poisoning Aboriginal families that get in their way, or cutting off parts of Indigenous bodies to keep as grisly souvenirs, are given nicknames like "Smasher" Sullivan, "Sagitty" Birtles and "Spider" Webb: names that (like those often attributed to comic-book villains) signal the marginal position to which such pathological characters are relegated in "normal" society. In reality, however, the brutal mistreatment of Aborigines concerned far more than a small minority of sadistic ex-convicts.

Interestingly, it is via the insights it offers into Will's relationship with his own name that the narration is most effective in communicating an image of the convict settler as underdog - a concept that, I repeat, is crucial to the construction of the "empathetic history" (Gall 95) of Australia's colonisation that The Secret River is primed to communicate.

Consider the scene of Will's chance encounter with the former captain of the convict ship that transported the Thornhills to New South Wales. Hailing Will in a "booming voice," calling out both his name and the name of the ship on which he had sailed - "Thornhill is it not? Alexander transport?" (172) -, Captain Suckling instantly destroys all the confidence that Will has managed to develop through his unstinting efforts to get on in the colony. "It was," the narratorial voice observes, "an old pain returning to find that William Thornhill felon, was waiting under the skin of William Thornhill landowner" (173, my italics).

The humiliating gesture Suckling uses to signify the pariah status the ex-convict occupies in his eyes, "shoo[ing] [him] away with both hands as if he were a dog" (173) deepens Thornhill's distress by forcing him to realise the impossibility of ever freeing himself of the degrading label of old lag. This confrontation with the power of his name to shackle him inescapably to his convict past is an epiphanic moment for Will whose actions are dictated henceforth by the knowledge that "there could be no future

18. See Anica Boulanger-Mashberg's excellent essay on how Grenville's memoir “functions as public authorial marginalia" to her novel (1).

19. To quote Gall "The moral economy that is constructed in the book leads to empathy with both Blackwood and Thornhill, and to the repudiation of Smasher [...]" (101).

20. That said, the name of the novel's main protagonist manages to suggest both the hostile environment that confronts the settler and his uphill struggle to survive. Similarly, "Blackwood" is the name of a settler who lives in the bush with "blacks." 
for the Thornhills back in London" (175) since "[t]heir very name - Thornhill - would carry the taint" (176).

The capacity of the ex-convict's name to cause psychic injury is further demonstrated in the grief Thornhill suffers when newcomers to the district mistakenly use another man's surname to refer to one of his sons. Having learned of his father's involvement in the massacre of a local Aboriginal tribe, Dick Thornhill (for whom the tribe's children had been playmates) leaves the family home and moves in with a settler named Blackwood. Already hurt by his son's defection, Will cannot bear to hear the name Dick Blackwood. It is "like the cut from a razor. There was the moment of cold nothing where the open flesh could be seen, and then the ache came on" (326).

Just as Sal's incurable homesickness is cued to elicit a sympathetic response, the pain Thornhill's name causes him positions the reader to view this "representative white settler" - the words are Grenville's own (Welch) - as a victim rather than a beneficiary of the process of colonisation - a discursive manoeuvre to which, historian Ann Curthoys argues, "white Australian popular historical mythology" not infrequently has recourse (2). Indeed, as Curthoys asserts:

There is a special charge associated with the status of victim in Australian historical consciousness, and it is notable how good non-Aboriginal Australians are at memorialising their own sufferings. [...] White settler suffering, [as anthropologist Andrew Lattas] suggests, becomes a means for conferring right of ownership to the land. (3, author's italics)

I have argued, then, that Grenville's consistent use of names to expose both the vulnerability and the hidden emotional damage suffered by her settler protagonists firmly situates The Secret River in the literary tradition of what Curthoys describes as "victimological narratives" (3). I shall now discuss how, having established the Thornhills' victim status, Grenville's narrative works to justify their possession of Aboriginal land.

\section{The Naming of "Thornhill's Point"}

Mindful of Carol Rose's postulate that "[P]roperty needs a tale, a story, a post hoc explanation," (98) I turn in this final part of my paper to a scene of cardinal importance in constructing the sub-textual explanation The Secret River offers of settler-Australian ownership of land.

As Sue Kossew observes, The Secret River's "teleological movement towards naming and possession overwrites and displaces the story of Indigenous dispossession" (112). In the scene in question (a pivotal one in both the narrative's development and the characterisation of the main protagonist), the author focuses on the euphoric act of naming Thornhill performs on his first visit to an area of the country that is being "opened up" for settlement. I read this scene as expressing Grenville's rejection of recent historical depictions of Australia's colonisation as a relentless process of land-grabbing by callous and venal settlers. In place of that bleak narrative she proposes a colonial fairy tale in which settler acquisition of Aboriginal territory is spun as a story of love at first sight.

Accordingly, Thornhill's naming of a stretch of land glimpsed on his first trip up the Hawkesbury River is portrayed as stemming from a poor man's sudden romantic 
longing to possess a riverine site of surpassing loveliness. ${ }^{21}$ Though Thornhill is the first to admit the unexpectedness of his reaction, "No one had ever spoken to him of how a man might fall in love with a piece of ground," (106) the narration makes clear that this is no passing fancy. Henceforth, the name "Thornhill's Point" hardly ever appears in the text without some simultaneous evocation of the settler's rapturous delight in the "teasing sparkle and dance of light among trees" (106) or "the marvel of that land, the way the sunlight fell so sweet along the grass" (111) etc. Merely to think of it is "a bead of warmth in his heart" (112).The emphasis placed on Thornhill's intoxication with the purely aesthetic qualities of the landscape is by no means innocent. In prompting the reader to infer that this was how early colonists responded to their new environment, the text reflects an instinctive resistance to the so-called "black-armband" version of Australian history according to which Australia's settlement was motivated principally by material greed and the desire for self-advancement.

Represented as the first step in what will become a process culminating in the settler's complete identification with the land, Thornhill's act of naming also signals the uprooted and downtrodden migrant's desire for a place in the world he can (in the most literal sense) call his own. After taking possession of this pretty dappled glade on the Hawkesbury, the ex-convict is reborn as "another man altogether" - a man for whom "This sky, those cliffs, that river" are the reflection of "where he [is]: not just in body, but in soul as well" (289, my italics). This mimetic appropriation of traditional Aboriginal relationships with "country" 2 is, of course, an absurd anachronism in a novel set in the first decades of the nineteenth century. Though indigenist fantasies of spiritual belonging to the land flourish in certain Anglo-Australian milieux today, they did not surface much before the early twentieth century. Until then, most newly arrived colonists tended to regard the land as being little more than a repository of potentially valuable resources, a commodity to be exploited, developed, made economically profitable. ${ }^{23}$

Like Grenville's representation of Thornhill's originary act of naming the land, the author's attribution of a spiritual dimension to her protagonist's feeling about "Thornhill's Point" is, I argue, part of her overarching aim to convey the legitimacy of the settler Australian's ownership of land. Further evidence to support this point can be found in the narratorial observation that, without the ceaseless labour of the Thornhills: "it would not take long for Thornhill's Point to melt back into the forest. [...] In no time at all, it would be as if the Thornhills had never called it theirs" (295, my italics). Suggesting that colonised territory has no meaningful identity beyond that of its natural history,

21. Contrary to Odette Kelada's contention that Thornhill's "drive" to own land, expressed in the "hypersexualised imagery of compulsive possession," (9) is a metaphor for the colonists' land lust and rapine, I suggest that it is more of an amorous yearning than a predatory sexual impulse that Grenville seeks to communicate. Gall, for example, describes The Secret River's "clear articulation of Thornhill's amorous relationship to the land" as being "[an] important feature of the novel" (102).

22. The term "country," (not preceded by any article), is used by Indigenous Australians to refer to the territory to which they belong. Explaining the special, multi-layered signification of this term in Aboriginal English, anthropologist Deborah Bird Rose points out that it is "not only a common noun but also a proper noun. People talk about country in the same way that they would talk about a person: they speak to country, sing to country, visit country, worry about country, feel sorry for country, and long for country. People say that country knows, hears, smells, takes notice, takes care, is sorry or happy. Country is not a generalised or undifferentiated type of place, such as one might indicate with terms like "spending a day in the country" or "going up the country." Rather, country is a living entity with a yesterday, today and tomorrow, with a consciousness, and a will toward life. Because of this richness, country is home, and peace; nourishment for body, mind, and spirit; heart's ease" (7).

23. For further discussion of this point see Strang (56-7). 
that the landscape bears no recognisable signs either of Indigenous occupation or of Indigenous peoples' efforts to develop it is one of the ideological arguments whitesettler societies habitually deploy to justify their denial of Aboriginal entitlement to land. Yet, because of the construction of the Thornhills as victims, and in the absence of any alternative narrative perspective to challenge the settlers' vision of events, what postcolonial analysis identifies as a cynical expression of colonial mawvaise foi, functions in Grenville's novel as a poignant reminder of the threat under which the hard-working colonist laboured.

The most egregious consequence of what I feel bound, in the circumstances, to call Grenville's perverse decision to represent Australia's colonial past from an exclusively settler point of view is that it inevitably causes the transgenerational trauma of Indigenous dispossession to fade, if not from sight entirely, then at least into the periphery of the reader's field of vision.

Closing the novel with a lengthy evocation of Thornhill's post-massacre angst, works moreover to reinforce that particular perceptual distortion. For inasmuch as Thornhill's inability to enjoy the rewards of his unremitting labour is portrayed as the heavy toll that settlers pay for their social ascendancy, and insofar as the narration depicts the protagonist's restless ocular questing for signs of an Aboriginal presence as a desire for atonement, ${ }^{24}$ there are, I think, reasonable grounds for arguing that Grenville's novel represents Australia's colonisation as a settler tragedy.

\section{Conclusion}

How then are we to account for this aporia at the heart of a work that Grenville dedicates "to the Aboriginal people of Australia: past, present and future"? To explain this paradox, I need to return to the notion of trauma evoked earlier in this discussion.

Building on Ann Curthoys' observation that "The self-chosen white victim finds it extremely difficult to recognise what he or she has done to others," (18) I argue that settler descendants' inability to perceive, let alone comprehend, the extent of psychic and socio-cultural damage that colonisation inflicted on Indigenous peoples is, in fact, a willed disability. ${ }^{25}$ As Gillian Cowlishaw remarks, Anglo-Australians' "sketchy and schematic knowledge" of the origins of settler-Aborigine relations, is the result of a "habitual blindness, a resistance to giving uncomfortable past events a place in consciousness" (100). It is, au fond, the same phenomenon that Stanner, using a different metaphor, described in the 1968 Boyer Lectures as "The Great Australian Silence" (18) or "a cult of forgetfulness practised on a national scale" (25).

The fact that, for many ordinary pioneer settlers, the extreme violence in which they had been involved during the frontier era, could not, in a later period, be recalled or spoken of, can, I think, best be understood in the light of Dominick LaCapra's assertion that "not everyone traumatized by events is a victim. There is the possibility of perpetrator trauma" (Writing History 79). Bain Attwood further notes that perpetrator trauma has the capacity to "affect not only contemporaries but also those born later" (Telling the

24. Atonement, that is, for what the narrative represents as a desperate act only reluctantly embarked on by Thornhill in order to protect his family.

25. Speaking of South Africa, Nadine Gordimer asserts that " $[\mathrm{t}]$ he segment of the white population to which I belong has become highly conscious of a dependency on distorted vision induced since childhood and we are aware that with the inner eye we have 'seen too much to be innocent"' (266, my italics). 
Truth 177, my italics). And it is, I think, this kind of second-hand trauma that accounts for the ignorance of the past that Grenville invokes both in her speech to the Australian Psychoanalytic Society and in Searching for The Secret River (See Collingwood-Whittick $139-40){ }^{26}$

In the last few decades, the "perpetrator trauma" afflicting many well-meaning settler descendants ${ }^{27}$ has, as I have indicated, been further exacerbated by the traumatogenic resurgence of the nation's brutal colonial past. Thanks to the new historiography, however, it has become increasingly difficult for non-Indigenous Australians to maintain their ignorance. The "collective and complicit amnesia" that previously enabled them to create "a sanitised colonial memory" 28 of Aboriginal dispossession is no longer possible. Yet given the "powerful patterns of denial [that] run like coarse threads through the unfolding drama of Australian land-taking," (Evans 13) many settler descendants, deprived of the refuge provided by their "habitual blindness," have responded by denying that the nation's history was ever as black as the "black armband" historians suggest.

A perfect illustration of this denialist reflex occurs in Grenville's memoir. Searching the archives for information about her great-great-great grandfather, Solomon Wiseman, Grenville is suddenly incensed by the negative image that the written record reflects: "I found myself catching fire with indignation," she confesses, "Notorious'? 'Deeply read in the corruption of human nature? How dare that pipsqueak [the Reverend Thomas Atkins] say that!" (88) Later, recounting how she transformed the biography of her ancestor into The Secret River, Grenville admits that, while she retained some characteristics of the historical character she "met in the archives," (188) she nonetheless introduced a "softness" into her characterisation of Thornhill that was clearly not evidenced in the results yielded by her research on Wiseman. Yet, she notes, "Once that softer part of his personality was drawn in, the violence he might inflict on the Aboriginal people took on a different quality" (188). And here, I think, we glimpse the intentionality subtending Grenville's colonial fiction.

The discursive strategies the author calls upon in her constructions of the power of names and naming are, I suggest, just another (albeit more subtle, less aggressive) form of the state of denial in which many casualties of the History Wars have found refuge. Rather than unconditionally acknowledging the truth of the traumatic past, Grenville repeatedly uses her protagonists' relationship with names to evoke the pathos of their condition, thereby attenuating the "moral horror" (Mulgan in Probyn-Rapsey 67) of Australia's frontier atrocities. This narratorial probing of the painfully vulnerable areas of settler experience, allows the author to de-emphasise the position of unbridled power colonists exercised over Indigenous Australians. Similarly, by sentimentalising the early settler's relationship with the land, her representation of Thornhill's act of naming

26. To speak of "perpetrator trauma" is in no way to minimise the weight of responsibility that must be borne by those involved in the many atrocities committed during the frontier era. As reflected in the anecdote Evans reports of the violent physical reaction experienced by Korah Halcomb Wills (a notorious slayer of Aborigines) after butchering Indigenous corpses in order to keep osteological specimens as souvenirs, even perpetrators of the most inhuman acts may succumb to feelings of shock at the "horrible and repulsive" crimes they have carried out (17-8).

27. My use of the term "well-meaning" here is intended to connote all that is encompassed by Albert Memmi's phrase "le colonisateur de bonne volonté" (49-73).

28. Quotations taken from Tony Birch's essay “"The Invisible Fire': Sovereignty, History and Responsibility,” a copy of which was given to me by the author during an interview on the $6^{\text {th }}$ of July 2009 . 
obfuscates "the savage process of dispossession" (Evans 20) on which the success of white-settler colonialism depends.

In her critical analysis of black-white relations in Australia, Sarah Maddison argues that if White Australians are "[t]o be relieved of [their] burden of collective guilt, [they] must find a way to break the bonds of solidarity with the perpetrators of historical and human justice" (194). What I hope to have shown is that, despite the traumatic shock described in her speech to the Australian Psychoanalytic Society, Grenville has not yet relinquished these bonds. Like many of her compatriots, she remains locked in what LaCapra (following Freud) describes as an "acting out" response to trauma (81), "narcissistically identified with the lost object," (81) the lost object in this case being the memory of Australia's colonial beginnings as heroic and benign.

\section{Sheila COLLINGWOOD-WHITTICK}

\section{Works Cited}

AттwоoD, Bain. "Unsettling Pasts: Reconciliation and History in Settler Australia." Postcolonial Studies 8.3 (2005): 243-59.

—. Telling the Truth about Aboriginal History. Crows Nest, NSW: Allen \& Unwin, 2005.

Blainey, Geoffrey. "Drawing Up a Balance Sheet of Our History." Quadrant 37.7-8 (July-August 1993): 10-15.

Blomley, Nicholas. "Landscapes of Property." Law \& Society Review 32.3 (1998): 567-612.

Boulanger-Mashberg, Anica. "In Her Own Margins: Kate Grenville's Searching for the Secret River as Marginalia to The Secret River." Limina 15 (2009): 1-9.

CARr, Richard. "New Narrative, Old Story." Antipodes (December 2006): 201-2.

Clark, Anna. "History in White and Black: A Critical Analysis of the Black Armband Debate." Special issue, Journal of Australian Studies 26.75 (2002): 1-11.

Collingwood-Whittick, Sheila. "The Haunting of Settler Australia." Postcolonial Ghosts. Ed. Mélanie Joseph-Vilain and Judith Misrahi-Barack. Les Carnets du CERPAC 8. Montpellier: PU de La Méditerranée, 2009. 125-42.

Cowlishaw, Gillian. Blackfellas Whitefellas and the Hidden Injuries of Race. Oxford: Blackwell, 2004.

Curthoys, Ann. "Expulsion, Exodus and Exile in White Australian Historical Mythology." Journal of Australian Studies 23.61 (1999): 1-19.

Evans, Raymond. "The Country Has Another Past: Queensland and the History Wars." Passionate Histories: Myth, Memory and Indigenous Australia. Ed. Frances Peters-Little, Ann Curthoys and John Docker. Canberra: Australian National U E-P, 2010. 9-38.

Eyerman, Ron. Cultural Tramma: Slavery and the Formation of African American Identity. Cambridge: Cambridge UP, 2001.

Ferrari, Justine, and Lauren Wilson. "Gillard Wants History Back to Basics." The Australian. 3 December 2007. 23 October 2013 <http://www.theaustralian.com.au/archive/news/gillardwants-history-back-to-basics/story-e6frgcoo-1111115017329>.

GaLL, Adam. "Taking/Taking Up: Recognition and the Frontier in Grenville's The Secret River." Special issue, JAS AL (2008): 94-104.

Gillis, John R. "Memory and Identity: The History of a Relationship." Commemorations: The Politics of National Identity. Ed. John R. Gillis. Princeton: Princeton UP, 1996. 3-24.

Gooder, Haydie, and Jane M. Jacobs. "On the Border of the Unsayable': The Apology in Postcolonizing Australia." Interventions 2.2 (2000): 229-47.

Gordimer, Nadine. "Living in the Interregnum." The Essential Gesture: Writing, Politics and Places. 1988. London: Penguin, 1989. 261-84.

GrenvilLe, Kate. The Secret River. Melbourne: Text Publishing, 2005.

- "Unsettling the Settler: History, Culture, Race and the Australian Self." Lectures, Essays and Short Pieces. Kate Grenville Official Website. 29 December $2012<$ http://kategrenville.com/node/73>.

- Searching for the Secret River. Edinburgh: Canongate, 2007.

- The Lieutenant. Edinburgh: Canongate, 2009.

—. Sarah Thornbill. Edinburgh: Canongate, 2012.

Hercus, Luise, Flavia Hodges, and Jane Simpson, eds. The Land is a Map: Placenames of Indigenous Origin in Australia. Canberra: Australian National UP, 2009. Available online at <http://epress.anu.edu. $\mathrm{au} /$ titles/the-land-is-a-map/pdf-download $>$. 
Kelada, Odette. "The Stolen River: Possession and Race Representation in Grenville's Colonial Narrative." JASAL 10 (2010): 1-15. 23 December 2012. <http://www.nla.gov.au/openpublish/ index.php/jasal/article/view/1698/2223>.

Koch, Harold and Luise Hercus, eds. Aboriginal Placenames: Naming and Renaming the Australian Landscape. Canberra: Australian National UP, 2009. Available online < http://epress.anu.edu.au/placenames_ citation.html>.

Kossew, Sue. "Voicing the 'Great Australian Silence': Kate Grenville's Narrative of Settlement in The Secret River." Journal of Commonwealth Literature 42 (2007): 7-18.

LaCAPra, Dominick. "Revisiting the Historians' Debate: Mourning and Genocide." History and Memory 9.1-2 (Spring-Winter 1997): 80-112.

—. Writing History, Writing Trauma. Baltimore: John Hopkins UP, 2001.

McKenna, Mark. "Writing the Past: History, Literature and the Public Sphere in Australia." Public lecture, Queensland College of Art, Brisbane. 1 December 2005. 10 February 2007 <www. humanitieswritingproject.net.au>.

—. "Silence Shattered With a Whisper to the Heart." The Australian. 4 March 2009. 12 December 2012 <http://www.theaustralian.com.au/arts/silence-shattered-with-a-whisper-to-the-heart/storye6frg8px-1111118953991>.

Maddison, Sarah. Beyond White Guilt. Sydney: Allen \& Unwin, 2011.

Mulgan, Richard. "Citizenship and Legitimacy in Post-Colonial Australia." Citizenship and Indigenous Australians: Changing Conceptions and Possibilities. Ed. N. Peterson, and W. Sanders. Melbourne: Cambridge UP, 1998.

Nelson, Camilla. "Faking it: History and Creative Writing." Text. 11 February 2007. 22 December 2012 <http://www.textjournal.com.au/oct07/nelson.htm>.

PRATT, Mary-Louise. Imperial Eyes: Travel Writing and Transculturation. London: Routledge, 1992.

Probyn-Rapsey, Fiona. "Complicity, Critique, and Methodology." ARIEL 38.2-3 (April-July 2007): 65-82.

Pulford, Donald. "The History Wars and Holy Day (The Red Sea): Andrew Bovell's Dramatic Black Armband." Antipodes (December 2006): 150-4.

Pybus, Cassandra. “Not Fit For Your Protection or an Honest Man's Company.' A Transnational Perspective on the Saintly William Dawes." History Australia 6.1 (2009): 121-7.

RitTer, David. "The Judgement of the World: The Yorta Yorta Case and the "Tide of History." Australian Historical Studies 123 (2004): 106-21.

Rolls, Mitchell. “Why Didn't You Listen: White Noise and Black History.” Aboriginal History 34 (2010): 11-33.

Rose, Carol M. Property as Persuasion. Boulder, CO: Westview, 1994.

Rose, Deborah Bird. Nourishing Terrains. Australian Aboriginal Views of Landscape and Wilderness, Canberra: Australian Heritage Commission, 1996.

Stanner, W. E. H. After the Dreaming: Black and White Australians - an Anthropologist's View. The Boyer Lectures 1968. Sydney: ABC, 1969.

STRANG, Veronica. Uncommon Ground: Cultural Landscapes and Environmental Values. Oxford: Berg, 1997. Welch, Denis. "Taken up.” New Zealand Listener. 208.3500 June 9-152007.

Wolfe, Patrick. "Structure and Event: Settler Colonialism, Time and the Question of Genocide." Empire, Colony Genocide: Conquest, Occupation, and Subaltern Resistance in World History. Ed. A. Dirk Moses. New York: Berghahn, 2008. 102-32. 